\title{
Analysis on the Motives Being a Fan or Fandom and the Possible Factor That Some Fans Performed Sasaengpaen/Fanatical Behavior
}

\author{
Yutong Pan
}

Dalian American International School, Dalian, China,116650

Email:2978266465@qq.com

\begin{abstract}
As developments of technology and communication are spreading widely across the world, an increased number of people contacts with brand new objects, trends, and figures by using social media. In this way, people build relationships with figures that they might worship and claim their adoration from the perspective of a follower. These are what people called "Fans". However, it is common to see these fans overreacting to idol-related issues. It is to be asked what can be the psychological reasons that cause people to become a fan and what factors cause them to be insanely irrational. To solve these problems, this paper utilizes data from other researches through the strategy of literature analysis and discovered two motives and one factor that contributes to the topic of question. It is revealed that motives such as finding self-identification in a group, having a sense of belonging, recognizing idolatry as a way to reward oneself and escaping from real-life sufferings are the main reasons that motivate a person to become a fan. Excessive addictive idolatry within a group that leads to disinhibit behavior due to deindividuation is the possible factor that causes the insanity. This study can help people better understand fan culture. In addition, it indicates the factors that might lead to a potentially harmful behavior from the fanatics, which means to prevent the ongoing behavior of the fanatical fans and to alleviate the potential ones, in order to contribute to a peaceful fan world and society.
\end{abstract}

Keywords: Self-identification, Escapism, Sasaengpaen, Fanatics, addictive idolatry, deindividuation

\section{INTRODUCTION}

In fan-related researches, many authors focused on the outcomes, whether beneficial or harmful that fandoms bring to their worshiping figures. Fans causing negative impact are examples like reports mentioning sports fans having sexual harassing and violent behavior during winning celebrations; [7] on the other hand, fan's support also contribute to economic success: in 2018, the internationally famous boy band BTS has made an amazing contribution to South Korea's economic by pulling $0.3 \%$ of their country's GDP, equivalent to half of the annual revenue of Korean Airlines. However, a lot of researches overlooks what are the fundamental reasons that make a fan become a fan. Collecting data using literature analysis, this essay studies the psychological origins, such as seeking identification within a group, finding a reward to escape from the pressure that causes a person to become a person that wishes to follow something or someone. Moreover, the factor like developing borderline addictive idolatry caused some of them to perform unethical behavior, such as sexual harassment, death threatening, and trespassing. This research is important because it justifies the existence of fandom. Many people do not understand why fans exist, but think that their presence only brings harm to society. Explaining the psychological reasons that motivate their fanship can help more people understand that fandom can positively impact a person. In this way, it can make more people begin to respect and understand this group. Besides, this study can be an alert to society, after understanding addictive idolatry, people can possibly prevent future unethical behavior around them in time when they discover similar symptoms.

\section{ANALYSIS OF THE REASONS FOR BECOMING A FAN}

"Fan" originates from the Modern Latin word 
"fanaticus" which means insanely but divinely inspired. [1] This word is used to describe a person who admires somebody or something or enjoys watching or listening to somebody or something a lot. Furthermore, fans can be separated into a variety of categories. For example, people that support a sport, watching competitions, are called sports fans; people that love Korean idols, buy albums and go to concerts, are called k-pop fans; due to their interests, many people uses their fanship advantage to build fan groups or engages in different fan circles. As the group or the tie between different people that share the same or similar interests, fandom could reveal the possible reasons for idolatry attraction.[2]

\subsection{Self and Group Identification}

Self-categorization within a group, finding and wanting to decide who they are in a small society, is defined as group identification. Individuals tend to have the intention to belong to a group. People do it by attributing themselves to one specific or multiple groups then experiencing empathetic emotions with the group. In addition, they apply characteristics of the group as a representation of their own personal traits. In this case, fans either participate or develop fandoms to fulfill the need to be identified or accepted. For example, sports fans identify a sense of honor and happiness according to their favorite teams' performance, and identify their team's failure as their own failure. [3] They perform actively before, during and after a game. As a fandom or the fan member of their team, they possess the high will to be supportive, such as screaming for points and painting on the face.[6] Same as the k-pop fans. They established a sense of acceptance and confirmed self-identity within their fandom through engaging in concerts, running fan-based events, buying albums and etc. Furthermore, a strong psychological connection was built between the worship and the fans. Followers identify their idols' performance, success and positive consequences as relevant to themselves. [3] Due to this, if their admiring figures developed fine accomplishments, fans' sense of identity and pride enhanced because they recognize their idol's success as their own success.

Table 1. Correlation matrix showing Pearson correlation coefficients between the below characteristics. [2]

\begin{tabular}{|l|l|l|l|l|}
\hline & Fanship & Happiness & $\begin{array}{l}\text { Self-Estee } \\
\mathrm{m}\end{array}$ & $\begin{array}{l}\text { Social } \\
\text { Connected } \\
\text { ness }\end{array}$ \\
\hline Fanship & 1 & $0.52^{*}$ & $0.23^{*}$ & $0.14^{*}$ \\
\hline Happiness & & 1 & $0.24^{*}$ & $0.35^{*}$ \\
\hline Self-Esteem & & & 1 & $0.33^{*}$ \\
\hline $\begin{array}{l}\text { Social } \\
\text { Connectedn } \\
\text { ess }\end{array}$ & & & & 1 \\
\hline
\end{tabular}

Note. ${ }^{*}$ Significance at the 0.01 level (2-tailed)

The above table was inserted from a research essay written by Derek A. Laffan from Dublin University. He made this table to reveal the correlation between fanship and the positive social outcomes it brings. As shown, maintaining fanship has a positive correlation with each of the characteristics. Based on Laffan's correlation table, it explains the article's prediction that fanship triggers fan's initiatives to maintain their following spirit: Fan's self-esteem, connection to the society, and the happiness that derives from fandom represents that these factors increased as individuals report being enhanced due to self-categorization of fanship. Beginning a fanship and identifying oneself within a group, people receive reinforcement in self-identification. In addition, followers acquire acceptance, happiness, and other factors through this process that drives their initiative to keep being a fan.

\subsection{Rewarding Escapism}

Besides seeking identification, escapism could be another reason for people admiring and following celebrities Seeking entertainment due to intentions to relief from the unpleasant reality is known as Escapism. Since they suffer from life, people start to seek entertainment, such as listening to k-pop music and going after a sport. It provides a world that allows the fan to escape from the unpleasant life.

Table 2. Escapism[9]

\begin{tabular}{|l|l|}
\hline $\begin{array}{l}\text { Name(Age/R } \\
\text { elationship } \\
\text { Status) }\end{array}$ & Summary of excerpts of the survey \\
\hline $\begin{array}{l}\text { Gina (25, } \\
\text { Married) }\end{array}$ & $\begin{array}{l}\text {-When feeling tired, I will reward myself with } \\
\text { k-pop music or videos. } \\
\text {-At the end of the day, I will watch k-pop for } \\
\text { sure, to release tiredness. }\end{array}$ \\
\hline $\begin{array}{l}\text { Alyani(24,Sin } \\
\text { gle) }\end{array}$ & $\begin{array}{l}\text {-When life gets hard, I need something to } \\
\text { entertain me, something that effectively } \\
\text { makes me forget the problem. } \\
\text {-When going to concert, you forget } \\
\text { everything but what's happening on the } \\
\text { stage. } \\
\text {-My idols help me feel better when facing } \\
\text { reality. }\end{array}$ \\
\hline $\begin{array}{l}\text { Athirah (24, } \\
\text { Single) }\end{array}$ & $\begin{array}{l}\text {-I feel greatly impacted by my idols. } \\
\text {-The wise statement that he made is } \\
\text { impressive. } \\
\text {-I believe that he used his power for a good } \\
\text { cause. }\end{array}$ \\
\hline Single
\end{tabular}

Above is a summary of the participants' response asserted from the research of reference 9. This table is derived from the representative responded that the 
author, Jenol and Pazil from Universiti Sains Malaysia, inserts from their research data. The authors gathered the response in order to discover fans' self-recognizing identity, and how fans feel when getting in touch with their idols. The table reveals the article's hypothesis on the state that a fan wants to receive through idolatry. In the response, representative participants Alyani and Gina similarly stated that they "feel relief and forget tiredness"[9]. It is clear that celebrities themselves, or their products are recognized by fans as pressure relief strategies that help them forget from real- life sufferings. When focusing on entertainment, fans' attention was attracted by the fantasies or excitement which their worship figures bring to them. As Pazil noted, fans understand that addicting to the fantasy of celebrities to escape from the unpleasant social life is a temporary action, but they still look forward to it.[9] Being a fan, apart from seeking motivation and happiness, fanship experience has brought some people a "reward" feeling. As a result, people are eager to seek such entertainment and consistently focus on related organizations. In this word, they become a fan since it can fill up their emptiness, and alleviate their stress from real life.

\section{FANATICISM AND ITS CAUSES}

\subsection{Fanaticism}

While most fans enjoy idol worship through appropriate actions, there are also a small number of fans who go to extremes. It is normal to cheer at their idols' concerts and support loudly their favorite sports teams inside the stadium. However, some fans perform irrational behaviors of excessive fanaticism, like but not limited to hurting their worshipping stars who disappointed them; those who are pathologically interested in the privacy of their idols. [1][5] In Korea, fans that performed the above actions are recognized as "Sasaengpaen". Moreover, fanaticism activities often have a bad influence on society. Firstly, idols' mental and physical health are threatened by these fanatics. Sasaengpaen follow their idol's schedule. They stalk their idol's car and stick them in traffic on purpose which sometimes caused car accidents. [5] Some of them even hurt their idol to get their attention. Besides, the unethical behavior of fanaticism also affects citizens' life. These fanatics not only have frequently hovered in corresponding housing estates harass their idol and interrupt the neighbors' life, but also violate people's safety since these fanatics always wander around weirdly.

\subsection{Causes of Fanaticism}

Different from finding self meaning or happiness on idols, a small amount people got addicted to fanship that developed a screwy addiction. As a result, due to excessively receiving self-think fantasies from their idols, some of them believes that they established a unique connection with their celebrities.[4] Sasaengpaen believe that they're no longer a parasocial relationship, but receive the unique indications, or seek unique hints from their celebrities. In addition, as Xiaodong Yue, a psychology professor of City University in Hong Kong often visit and teach in Nanjing University, South China Normal University and Nanjing Normal University, introduced in his research that such borderline behavior can have three levels of degrees: (1) Entertainment--social, (2) Intense--personal, (3)Borderline--pathological. Above level two, people with addictive behavior might perform compulsive tendencies and even emerge uncontrollable illusions and behaviors. [4] Therefore, crazy followers might intend to intrude on privacy, even hurting their beloved fame figure. For example, actions such as stalking, writing letters to artists in blood, trespassing, mob, insulting, and the threat or even riot[2][8] can be done by fans not limited to idols fan, but to athletes supporters and others followers despite online or offline. Moreover, such behavior might be encouraged unconsciously inside a fandom or fan circle. According to the survey that Xiaodong Yue's research, the relationship between second-order factor's data for his Idol Worship Questionnaire (Second level): Identify with 3 items (level 1, 0.635), Attachment 3 items (First order, 0.876), Romanticize 3 items (Level 1, 0.702), Idealization 3 items (first order, 0.772), Consumability 3 items (first level, 0.770), and Celebrity Attitude Scale (Second level): 10 Entertainment/Social Items (Level 1, 0.956), Personalization 9 items (Close) (Level 1, 0.980, ), and Obsession 4 items (Pathological) (Level 1, 0.983) reveals that having a membership in active fan club has a significant influence to the addictive idolatry $(\beta=$ 0.259 ), but has less association comparing with people who develop self-identification idolatry, $(\beta=0.130)$. Such difference and effectiveness are statistically significant, $(\mathrm{X} 2(1)=22.5, \mathrm{p}<0.001)$ [4] which proves the article's previous statement. The result of the data is explainable by the phenomenon of deindividuation. This phenomenon happens people act differently, due to the anonymity feeling when staying in crowds or groups. Furthermore, such disinhibition causes impulsive or even antisocial behavior. The sense of responsibility was alleviated when staying in a group. Under this situation, fans are encouraged by their instincts.[7] As a result, irrational behavior such as riots or stalking might be conducted by the people who developed borderline addictive idolatry. In comparison with the fan that maintains a decent self-identification idolatry, addictive fans performed in extreme feverish. Thus, forming a group, or staying in a group, increases their chances of performing the borderline activity.

\section{CONCLUSION}

At the beginning of the article, it described the 
definition of a fan, briefly categorized several types of fans, and mentioned the essential research focuses in this article: why people want to be fans, and why some performed intruding behavior. Throughout the entire passages of analysis, it is understood that (1) finding identification, (2) escaping from the unpleasant reality motives people become a fan. Belong to a group of people who shares the same interests, not only would it bring significant happiness, but also an increase in self-esteem and benefits one's thinking in self meaning. However, some people developed a wrong relationship with their fame figure. As addiction for these types of people reaches to level above intense--personal, they start to develop impulsive actions and illusions. Under this situation, joining a fan group would likely push fanatics to execute their intruding plans. Since Sasaengpaen or those who develop addictive adoration will feel disinhibited and less self-aware due to the effects of deindividuation in a fan group, they're more instinctively pushed to behave irrationally.

For improvement, this paper can broaden its areas of research. Besides doing the popular focused Sports and K-pop fans, it can try to include not so popularly focused fandoms such as anime fans, furry fans, and vtuber fans. It can also try to further discuss when fans worshiping idols are no longer living persons. This research's future focuses is to gather more data from non -popular fandoms, and try to develop the topic more comprehensively. Thus, it could be applied to a larger population of fans.

\section{ACKNOWLEDGMENTS}

Firstly, I want to thank my friend Fiona who is a fan that enlightens me to research this interesting topic. Secondly, I want to thank my counselor who provides me with useful ideas towards my topic. I also want to acknowledge the teacher that once guide me and correct my mistakes. With their accompany, I am able to research my interests and finish an essay based on them

\section{REFERENCES}

[1] Rashi Kakkar. What makes a sports fan into a sports fanatic. $\quad$ Firstpost. 2014:1 https://www.firstpost.com/blogs/what-makes-a-spo rts-fan-into-a-sports-fanatic-1667233.html

[2] Laffan, D. A. (2020):5-6, 21. Positive Psychosocial Outcomes and Fanship in K-Pop Fans: A Social Identity Theory Perspective. Psychological Reports. doi: https://doi.org/10.1177\%2F0033294120961524. [Link to article: https://journals.sagepub.com/eprint/7RFN3NQNZ RFDYWR4C76V/full]

[3] David Roque. The psychology of fandom
Understanding the etiology, motives, and implications of fanship. Routledge. 2010:3-4

[4] Xiaodong Yue, Zhouqiao Zhang. On the difference between the role of halo and role model in idol worship. Semimonthly. 2021:1-8

[5] J. Patrick Williams \& Samantha Xiang Xin Ho(2016): 81-82. "Sasaengpaen” or K-pop Fan? Singapore Youths, Authentic Identities, and Asian Media Fandom, Deviant Behavior, 37:1, 81-94, DOI: $10.1080 / 01639625.2014 .983011$

[6] Shirley Wang. Sports Complex: The Science Behind Fanatic Behavior. APS. 2006: 1 https://www.psychologicalscience.org/observer/spo rts-complex-the-science-behind-fanatic-behavior

[7] Beth Johnson. The Social psychology of the Creation of a Sports fan identity: A Theoretical Review of the Literature. Athletic Insight. Volume 5, Issue 2. June 2003: 2-3

[8] Thomas Van Schaik. The Psychology of Social Sports Fans: What Makes Them So Crazy? Sportsnetworker. 2012: 1 http://www.sportsnetworker.com/2012/02/15/the-p sychology-of-sports-fans-what-makes-them-so-craz y/

[9] Nur Ayuni Mohd Jenol, Nur Hafeeza Ahmad Pazil. Escapism and motivation: Understanding K-pop fans well-being and identity. Malaysian Journal of Society and Space. 2020: 341-344 